Vol. 2 No. 3, 2021

\title{
MANAGEMENT OF LAND USE EFFICIENCY IN THE CONTEXT OF MARKET CHANGES
}

\author{
Anna Yakymovska'
}

\begin{abstract}
The purpose of the article is to study the peculiarities of the use of agricultural land resources, which are one of the determinants of economic development and environmental security of the state. The relevance and importance of the search for development scenarios of agricultural land market, the definition of the content and implementation of state regulation in the sphere of agricultural land use, the presence of a large set of unresolved issues in this area led to the choice of topic. The purpose of the article is to study the development of the agricultural land market in Ukraine. Methodology. Methods of analysis, comparison and generalization of research results, economic, statistical and graphical methods were used to write the article. The source of data for the scientific research were reports and statistical information of the Ministry of Finance of Ukraine and the State Treasury Service of Ukraine. Results. The study showed that the transformation of land ownership relations in the absence of environmental and economic justification of the redistribution of land and territorial resources has led to significant changes in the composition and structure of agricultural land, as well as the ecological imbalance of the land fund. In turn, this has caused many environmental and economic problems in the domestic system of land use, including: excessive parcellation of land, violation of crop rotations, introduction of monoculture and, as a consequence, deterioration of soil quality, reduction of its fertility, increased erosion and land degradation. It is proved that the development of land and legal system should be based on a multilevel model of state regulation of agricultural land markets, which, in contrast to the existing one, provides for the development of a secondary market, land auctions and mortgages, involvement of unclaimed land into market turnover. Practical implications. Since the practice of managing agricultural enterprises in market conditions shows that the main thing is not the availability of land resources, but the efficient use of their potential, so the need to create a reliable economic mechanism to ensure the efficient use of land resources and the protection of land fertility is a priority. The breadth and versatility of land problems, their connection and dependence on socio-economic, political and environmental factors necessitate further study of this issue.
\end{abstract}

Key words: land resources, land market, state regulation, environmental factors, land use efficiency, government support.

JEL Classification: O13, Q15, Q18, Q24

\section{Introduction}

Land is a unique natural resource of any state, which plays an exceptional role in the life and activities of society. However, it should be noted that Ukraine is still at the stage of recognizing the real value of land and the formation of appropriate mechanisms for its rational use. Changes in economic life associated with the creation of a modern market economy require fundamentally new approaches to the formation and implementation of land policy. The problem of land resources management is the most important in solving the problems of socio-economic

Corresponding author:

${ }^{1}$ National University of Life and Environmental Sciences of Ukraine, Ukraine

E-mail: anysy87@ukr.net

ORCID: https://orcid.org/0000-0002-5983-2069 development. The management of land resources is determined by the special multifunctional role of land in society, its natural limitations and irreplaceability in any sphere of economic and other activities. Land management is an objective process and a system of measures (legal, administrative, economic, environmental, etc.) to perform the social and production functions of land.

The current stage of economic reform in Ukraine requires rethinking the role and place of land as the most important element of agricultural production and as an asset involved in the market turnover. A necessary condition for the formation of a full- 
fledged market of agricultural land in Ukraine is the development of mechanisms and tools for its regulation in accordance with the directions of internal public policy.

In the majority of countries of the world, the land market is one of the most regulated markets by the state, with special attention paid to agricultural land.

The issue of solving the problems of state regulation of agricultural land market, the use of land resources, the current state and aspects of the rational and effective use of agricultural land is given considerable attention in the works of O. Budziak, A. Verveyko, V. Dankevych, D. Dobryak, O. Dorosh, A. Dibrova, T. Yevsyukov, A. Martin, M. Stupen, A. Tretyak, S. Rohach and others.

The relevance and importance of the search for development scenarios of agricultural land market, the definition of the content and mechanisms of state regulation in the sphere of agricultural land use, the presence of a large set of unresolved issues in this area led to the choice of topic, purpose and objectives.

\section{Analysis of the current state of land use}

The land and resource potential of Ukraine is 60.3 million hectares of land, of which 41.3 million hectares are occupied by agriculturally used areas (68.5\%). It should be emphasized that there have been no significant transformations in the structure of the land fund in recent years, but the amount of agriculturally used areas has slightly decreased and the amount of built-up land has increased (Figure 1). That is, agricultural land is withdrawn from turnover, which causes a significant deterioration of its quality, and in some cases the soil loses its fertility.

During the years of the land reform, the composition and structure of agricultural land changed (Table 1). The area occupied by hayfields, fallows, and pastures has decreased. The area of arable land, on the contrary, increases. Given the overall reduction in the area of agricultural land, it can be concluded that the ecological condition is deteriorating.

The high level of plowing is one of the main reasons for the development of erosion processes. Erosion control is one of the central problems in agriculture. It consists in removing degraded, unproductive and technogenically polluted lands from intensive agricultural use and transferring them to agricultural land through conservation (Yasinetskam, 2016).

In addition, from 2010 to 2019 there were some changes in the structure of crop production areas of major crops. Figure 2 shows that the structure of crop production areas has been severely disrupted recently. In the pursuit of profit, crop rotations are thoughtlessly saturated with highly profitable industrial crops. In particular, the share of sunflower in the total structure of crop production areas has increased from 17 to $21 \%$ as a result of the profitability of growing these crops. However, the increase in acreage of these crops

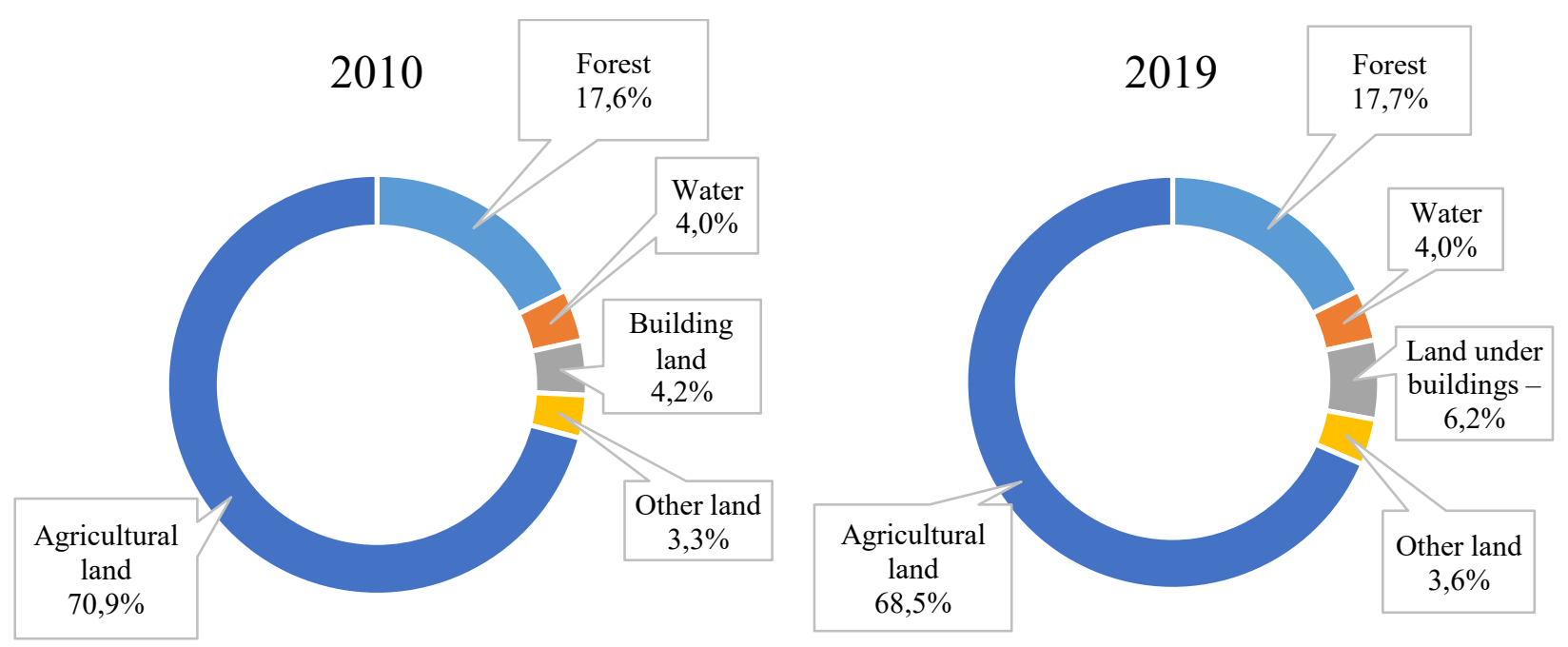

Figure 1. Composition and structure of the land fund of Ukraine

Source: calculated by the author according to the data (State Statistics Committee of Ukraine, 2019) 
Table 1

Dynamics of changes in the structure of agricultural land in Ukraine

\begin{tabular}{|c|c|c|c|c|c|}
\hline \multirow[b]{2}{*}{ Type of land } & \multicolumn{2}{|c|}{2010} & \multicolumn{2}{|c|}{2019} & \multirow[b]{2}{*}{$2019 \bigotimes$ to 2010} \\
\hline & $\begin{array}{l}\text { Area, thousand } \\
\text { hectares }\end{array}$ & $\%$ & $\begin{array}{l}\text { Area, thousand } \\
\text { hectares }\end{array}$ & $\%$ & \\
\hline Agricultural lands, of which: & 41576,00 & 100,00 & 41310,90 & 100,00 & $-265,10$ \\
\hline arable land & 32476,50 & 78,11 & 32757,30 & 79,29 & 280,80 \\
\hline conversions & 310,20 & 0,75 & 166,70 & 0,40 & $-143,50$ \\
\hline perennial plantations & 896,50 & 2,16 & 852,70 & 2,06 & $-43,80$ \\
\hline hayfields & 5481,90 & 13,19 & 2283,90 & 5,53 & $-3198,00$ \\
\hline pastures & 2410,90 & 5,80 & 5250,30 & 12,71 & 2839,40 \\
\hline
\end{tabular}

Source: calculated by the author according to the data (State Statistics Committee of Ukraine)

with a parallel decrease in the share of legumes in the overall cropping pattern does not indicate a favorable impact on the growth of soil fertility and improvement of land quality.

Although agriculture is the industry where the "land" ecosystems work best for humans, it should not be forgotten that its potential cannot indefinitely be turned into property without the contribution of the consumer. Such a contribution is the use of organic and mineral fertilizers, which will provide the basis for increasing the level of potential (resource) competitiveness of agricultural production. The use of mineral and organic fertilizers helps to maximize land productivity, reduce production costs and improve profitability. Analysis of the dynamics of the use of mineral fertilizers for crops in enterprises of Kyiv region (Figure 3) shows that since the 2000 s there is a tendency to increase the fertilized areas (from 28 to 92\%) of mineral fertilizers and fertilizer doses from 22 to $122 \mathrm{~kg}$ per hectare.

Conversely, organic fertilizers and the proportion of the area of their application decreases every year (Figure 4). Thus, in 2019, compared with 2000, the use of organic fertilizers decreased by half. The share of fertilized area increased slightly by $9.4 \%$ in 2018 . In 2019 , however, this figure decreased again. As a result, agricultural enterprises do not receive a potentially possible harvest, which leads to the problem of food security at the regional level.

Increasing the application of mineral fertilizers has not changed the situation. As can be seen from Figure 2, in the structure of sown areas an increasing share of industrial crops, which are now highly profitable. The risk of bankruptcy, if the economic potential to meet their needs is small, makes the landowner or land user forget about the "land" ecosystem. There's no excuse for that. What is needed is an effective management system that, through the land management function, will stop such land consumption (Zaghnij, 2013).

\section{Land resources management in the context of land market implementation}

The economic essence of land management in market conditions is to justify measures taken as the implementation of state land policy and aimed at improving the efficient use of land as an economic resource. The strategic goal of state

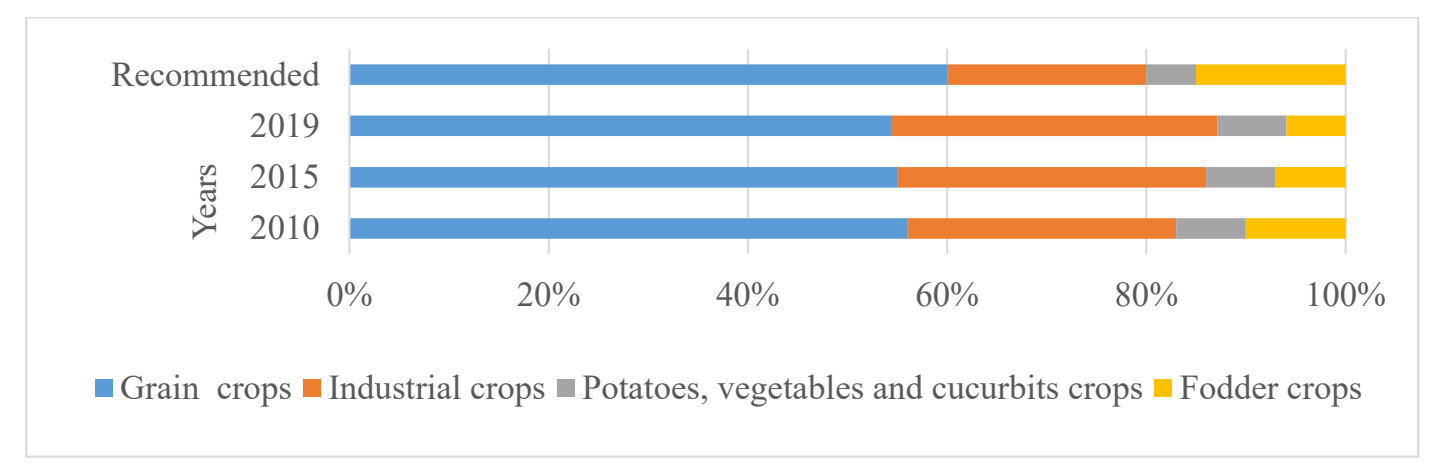

Figure 2. The structure of crop production area in agricultural enterprises of all categories

Source: calculated by the author according to the data (State Statistics Committee of Ukraine) 


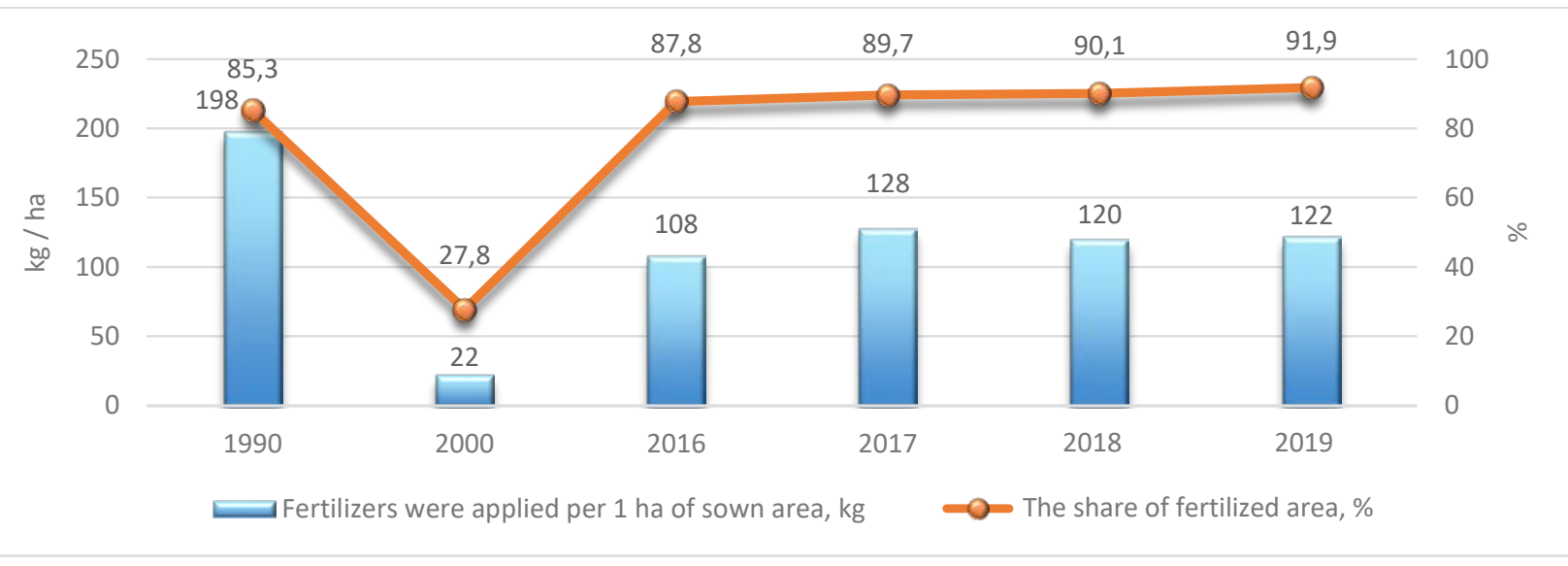

Figure 3. Application of mineral fertilizers to the soil in agricultural enterprises of Kyiv region

Source: calculated by the author according to the data (State Statistics Committee of Ukraine)

policy in the area of land resources management is to provide conditions for effective land use and land market development as one of the key conditions for sustainable economic development of the country and the improvement of the wellbeing of its citizens.

It should be noted that according to StateGeoCadastre, about 300 thousand hectares of agricultural land remain unclaimed. Many land-owners use their land without proper documentation, and the hromadas where most of these unclaimed shares are located lose significant amounts of taxes.

At the same time, it should be emphasized that the key strategic goal of land transformations is economic efficiency. That is, land should be owned by people who can use it rationally. Along with this, land use is an important element of sustainable development of territories as well as the agricultural sector of the economy. However, in the domestic field, many problematic aspects hinder the provision of such growth, taking into account the quality of land (Stupen, 2019).

As it is known, the vast majority of modern agricultural enterprises are enterprises based on private ownership of land and using rent in their activities. Thus, ownership, especially private ownership, refers to the fundamental economic factors that change a person's psychology, and vision of real economic processes. Therefore,

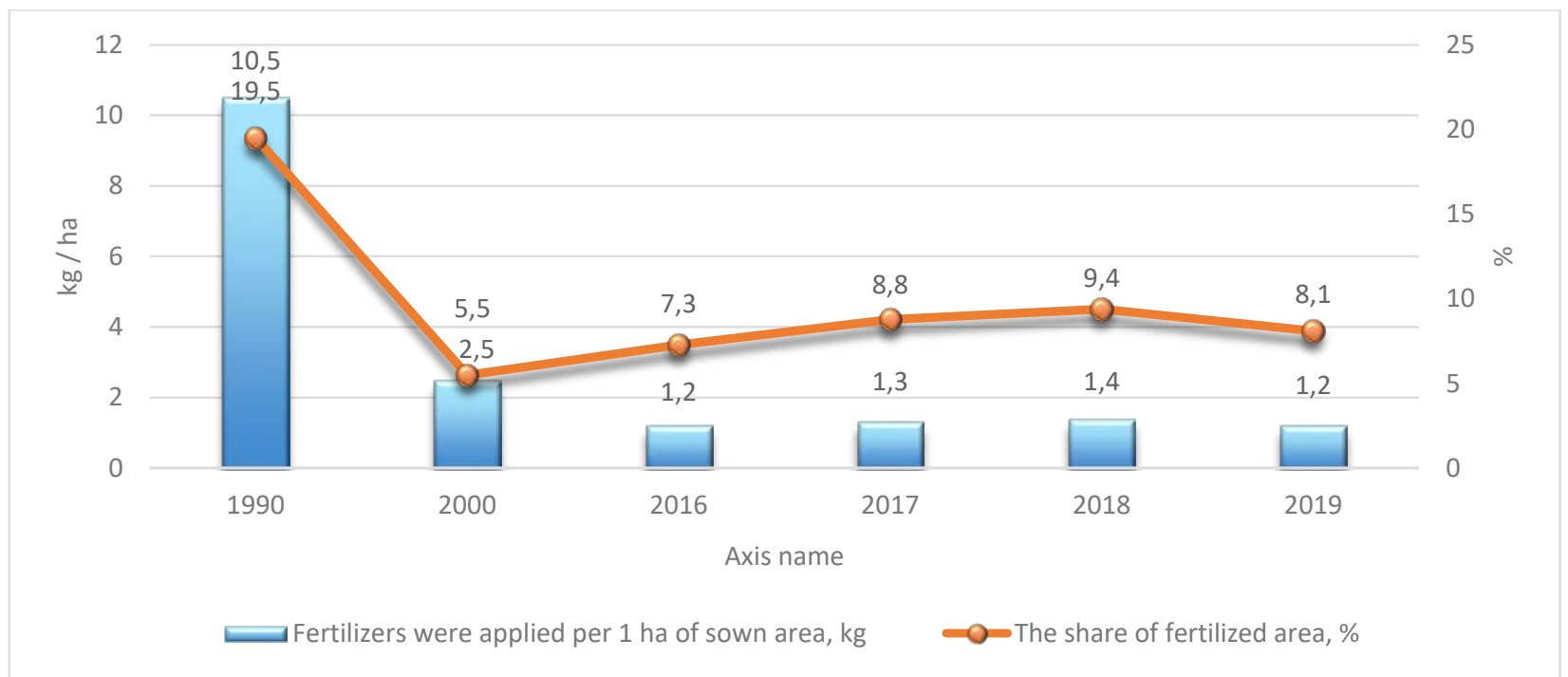

Figure 4. The use of organic fertilizers in the soil in agricultural enterprises of Kyiv region

Source: calculated by the author according to the data (State Statistics Committee of Ukraine) 
private property determines the responsibility of man not only to himself, but also to his descendants and, ultimately, to society as a whole. After all, when a producer is unable to effectively and rationally dispose of property under market conditions, to multiply it and transfer the capital for further development, this property may be lost permanently.

This provision primarily relates to private land ownership. This situation can be clearly seen in the process of land reform in Ukraine. Land was privatized and new agricultural enterprises were created on the basis of private ownership, namely: instead of collective and state farms, holdings, associations, business partnerships, private enterprises, production cooperatives, farms, etc. were formed. Land use under these conditions has acquired a different essence. In addition to the use of land owned by an individual or a legal entity, its owners have the right to own and dispose of it.

It is worth noting another feature of the transformation of land relations: before the introduction of the land reform, the size of farms by area of agricultural land on average ranged from 2,000 to 5,000 hectares. However, due to the emergence of various organizational and legal forms of farming in the agricultural sector today we can observe a significant diversity in the size of agricultural enterprises from 5 hectares to more than 10 thousand hectares. Currently, slightly more than 23.4 thousand agricultural enterprises have land up to 100 hectares. However, given that this group of farms occupies about $48 \%$ of the total number of agricultural enterprises, they account for only $4.1 \%$ of all agricultural land. At the same time, slightly more than 4,741 agricultural enterprises using more than 1,000 hectares of land, representing $9.8 \%$ of the total number of enterprises, concentrate $77.0 \%$ of all agricultural land (Table 2).

The growing concentration of agricultural land is conditioned by the growing investment attractiveness of the agrarian sector of the economy and necessitates the strengthening of state regulation of this process, in particular, the concentration of large tracts of land in the largest agro-industrial corporations and the strengthening of control over the monopolization of agricultural land. Therefore, one of the tasks of public authorities is to form such a system of agricultural land use and mechanism of its redistribution in favor of effective owners, while respecting the legitimate interests of all subjects of land relations. In general, the directions of state regulation of land relations are aimed at finding an effective landowner and land user, which will solve environmental issues in a complex, contribute to the creation of an institutional system that ensures a continuous process of redistribution of land ownership in order to improve their use in agricultural production.

The adoption of the Law of Ukraine "On the Land Market" taking into account the proposed approaches makes it possible to limit state regulation of the procedure of alienation of rights to agricultural land by owners, which will ensure the introduction of the market turnover of rights to agricultural land while minimizing its potentially negative environmental and economic consequences. Thus, during the period from July 1, 2021 to October 9, 2021 inclusive (according to the StateGeoCadastre) in Ukraine there were expropriated 28,288 land plots with a total area of 70.57 thousand hectares. The

Table 2

Distribution of enterprises engaged in agricultural activities by the size of agricultural land in 2019

\begin{tabular}{|l|c|c|c|c|}
\hline \multirow{2}{*}{ Groups of enterprises } & \multicolumn{2}{|c|}{ Number of enterprises } & \multicolumn{2}{c|}{ Area of agricultural land } \\
\cline { 2 - 5 } & units & $\begin{array}{c}\text { percentage of the total } \\
\text { number of enterprises }\end{array}$ & $\begin{array}{c}\text { thousand } \\
\text { hectares }\end{array}$ & $\begin{array}{c}\text { percentage of the total } \\
\text { area of agricultural land }\end{array}$ \\
\hline $\begin{array}{l}\text { Enterprises that had agricultural land, } \\
\text { including land, ha }\end{array}$ & 38523,00 & 79,4 & 20113,60 & 100,00 \\
\hline no more than 100,00 & 23393,00 & 48,23 & 818,60 & 4,07 \\
\hline $100,01-500,00$ & 7717,00 & 15,91 & 1890,20 & 9,40 \\
\hline $500,01-1000,00$ & 2672,00 & 5,51 & 1918,60 & 9,54 \\
\hline $1000,01-2000,00$ & 2410,00 & 4,97 & 3451,90 & 17,16 \\
\hline $2000,01-3000,00$ & 1056,00 & 2,18 & 2566,90 & 12,76 \\
\hline more than 3000,00 & 1275,00 & 2,63 & 9467,40 & 47,07 \\
\hline Enterprises that had no agricultural land & 9981 & 20,6 & $\mathrm{x}$ & $\mathrm{x}$ \\
\hline
\end{tabular}

Source: calculated by the author according to the data (State Statistics Committee of Ukraine) 
average cost of one hectare of expropriated land is $43879 \mathrm{UAH}$.

Of these, the following were acquired:

- under purchase and sale agreements (23600 land plots with a total area of 61.22 thousand hectares);

- under exchange agreements (198 land plots with a total area of 282 hectares);

- under gift agreements (4,476 land plots with a total area of 9.06 thousand hectares);

- 14 land plots with a total area of 3 hectares were purchased by individuals under life care contracts (AgroPolit.com, 2021).

\section{Conclusion}

Land resources require comprehensive management, which consists of purposeful coordination of efforts, rational choice of forms of land ownership and forms of organization of its use. In general, it is believed that land management involves the achievement and further development of rational land tenure, land management and land use, determining the optimal proportion of land distribution between sectors of the economy, taking into account economic and environmental conditions. The primary function of the land market is to facilitate the transition of land from inefficient to efficient producers. Its purpose is to turn land into capital that can be used to generate additional income for landowners. Only under conditions of land ownership will land become a functioning economic resource capable of benefiting both large agricultural enterprises and the broader population that owns land.

Analysis of the use of land resources in Ukraine shows that $65.8 \%$ of the total area of land resources of our state is occupied by agricultural land. However, a significant part of land resources is losing its fertility and degrading. Thus, to protect the soil cover it is necessary to use the principles of ecological and landscape farming, in which the ratio of agricultural land and natural complexes will be economically feasible and environmentally justified. Therefore, there is a need for an effective management system that will provide conditions for the effective use of land and the development of the land market as one of the key conditions for sustainable economic development of the country and the well-being of its citizens.

Thus, today and in the future the legislative regulation of agricultural land turnover will have positive socio-economic consequences. The full implementation of the right of private ownership of agricultural land by citizens of Ukraine will be realized. The objective market value of agricultural land will be established in the process of its economic turnover and the growth of land capitalization. There will be an opportunity to attract additional credit resources in the agricultural sector of the economy of Ukraine. This will create conditions for the rational redistribution of agricultural land and optimize its use. All of the above will ensure the transparency of land transactions and increase the economic well-being of the population.

\section{References:}

Zaghnij, D. M., \& Vervejko, A. P. (2013). Socialjno-ekonomichni osnovy upravlinnja vykorystannjam zemeljnykh resursiv siljsjkoghospodarsjkykh pidpryjemstv [Socio-economic bases of management of use of land resources of agricultural enterprises: monograph]. Kharkiv: NTMT. (in Ukrainian)

Stupen, R. M. (2019). Ekologho-ekonomichni zasady rozvytku rynku zemelj siljsjkoghospodarsjkogho pryznachennja v ukrajini [Ecological and economic basis for the development of agricultural land market in Ukraine] (PhD Thesis), Lviv: Lviv National Agrarian University.

Yasinetska, I.A. (2016). Osoblyvosti racionaljnogho upravlinnja zemeljnymy resursamy [Features rational management of land resources]. Scientific Bulletin of Uzhhorod National University, 8(2), 127-130.

Derzhavna sluzhba statystyky Ukrainy (2017). Ekonomichna statystyka [Economic statistics]. Kyiv. Available at: http://www.ukrstat.gov.ua/ (accessed 31 October 2021).

AgroPolit.com Hot agricultural policy (2021). Rynok zemli v Ukrajini - 100 dniv: cina zemli, kiljkistj prodanykh pajiv, rozmiry paju [Land market in Ukraine - 100 days: land price, number of shares sold, unit size]. Available at: https://agropolit.com/news/22071-rinok-zemli-v-ukrayini--100-dniv-tsina-zemlikilkist-prodanih-payiv-rozmiri-payu (accessed 31 October 2021). 